\title{
Çocuklarda Toplum Kökenli Pnömoniye Yaklaşım: Amerikan Çocuk Enfeksiyon Derneği Rehberi
}

\author{
Şebnem Özdoğan ${ }^{1}$
}

\begin{abstract}
ÖZET:
Çocuklarda toplum kökenli pnömoniye yaklaşım: Amerikan çocuk enfeksiyon derneği rehberi

Çocuklarda toplum kökenli pnömoni (TKP) özellikle gelişmekte olan ülkelerde önemli bir morbidite ve mortalite nedenidir. Tüm dünyada 5 yaş altı çocuklarda ölüm nedenlerinin başında gelir. TKP tanı ve tedavisine yönelik rehberlerin morbidite ve mortaliteyi azalttığı gösterilmiştir. Rehberler tanı ve tedavide tek yaklaşım değildir. Pediatrik TKP'nin klinik seyri çok farklılıklar gösterdiği gibi aynı patojen farklı klinik tabloya neden olabilir. Rehberler hastayı takip eden klinisyenin değerlendirmesinin yerini alamaz. Bu çalışmada çocuklarda TKP'nin tanı ve tedavisi Amerikan çocuk enfeksiyon hastalıkları derneğinin yayınladığı rehber ışığında tartışılmaktadır.

Anahtar kelimeler: Toplum kökenli pnömoni, çocuk, rehberle

\section{ABSTRACT:}

The management of community acquired pneumonia in children: guidelines by the pediatric infectious diseases society of America

Community-acquired pneumonia (CAP) is a significant cause of morbidity and mortality in children, especially in developing countries. Worldwide, CAP is the leading cause of death in children younger than five years. Guidelines for the management CAP have been demonstrated to decrease morbidity and mortality rates. They do not represent the only approach to diagnosis and therapy; there is considerable variation among children in the clinical course of pediatric CAP, even with infection caused by the same pathogen. It does not replace the need for the application of clinical judgment to each individual presentation. In this study we aim to discuss the diagnosis and management of CAP in children based on clinical practice guidelines by the pediatric society and the infectious diseases society of America.
\end{abstract}

Key words: Community acquired pneumonia, children, guidelines

\section{Ş.E.E.A.H. Tıp Bülteni 2015;49(3):163-73}

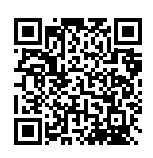

\footnotetext{
'Şişli Hamidiye Etfal Eğitim ve Araştırma Hastanesi, Çocuk Sağlı̆̆ı ve Hastalıkları Kliniği, istanbul - Türkiye

Yazışma Adresi / Address reprint requests to: Şebnem Özdoğan,

Şişli Hamidiye Etfal Eğitim ve Araştırma Hastanesi, Çocuk Sağlığı ve Hastalıkları Kliniği, istanbul - Türkiye

E-posta / E-mail: ozdogan65@hotmail.com

Geliş tarihi / Date of receipt: 1 Haziran 2015 / June 1, 2015

Kabul tarihi / Date of acceptance: 31 Ağustos 2015 / August 31, 2015
}

\section{GíRiş}

Tüm dünyada çocukluk çağı ölümlerinin en önemli nedeni pnömonidir. Dünya sağlık örgütü verilerine göre her yıl 5 yaş ve altında 155 milyon çocuk pnömoni tanısı almakta, 20 milyona yakını hastaneye yatırılmakta, 2 milyondan fazla çocuk pnömoni nedeniyle ölmektedir $(1,2)$.

Ülkemizde, Türkiye Hastalık Yükü Çalışması'na göre solunum yolu infeksiyonları; 0-4 yaş grubunda $\% 13.4,5-14$ yaş grubunda \%6.5 ile en sık ikinci ölüm nedenidir ve 0-14 yaş grubundaki tüm ölümle- rin \%14'ünden sorumludur (3).

Çocukluk çağında, ayaktan tedavi edilen hastaların $\% 23$ 'ü, hastaneye yatırılan hastaların ilk yaşta \%33-50'si, tüm yaş gruplarında \%29-38'i pnömoni tanısı almaktadır. Tüm toplumda gelişen pnömonilerin \%37'si çocukluk yaş grubunda görülmektedir (4).

\section{Tanımlar}

Pnömoni: Akciğer parankimininde (viseral plevra, bağ dokusu, havayolu, alveoller ve vasküler yapılar dahil) sıklıkla bakteriyal ve virüslerin neden olduğu 
inflamasyon olarak tanımlanır.

Toplum kökenli pnömoni: Önceden sağlıklı olan, yakınmalarının başlangıcından 14 gün öncesine kadar hastanede yatış öyküsü olmayan bir kişide, toplumda günlük yaşam sırasında ortaya çıkan pnömonidir (5).

Alt solunum yolu infeksiyonu: Bronşit, bronşiolit, pnömoni veya bu üçünün kombinasyonu için kullanilır.

\section{Etiyoloji}

Tablo 1'de yaşa göre pnömoni etkenleri gösterilmiştir $(6,7)$. Sıklıkla viral ve bakteriyal patojenler pnömoni nedenidir. Fungal ve mikobakteriyal pnömoniler bu rehberin kapsamı dışında tutulmuştur. Iki yaşın altında çocukların \%80'ininde viral etkenler sorumlu iken, daha büyük çocuklarda özellikle 10-16 yaş arasında viral etkenlerin daha az sıklıkla pnömoni nedeni olduğu bilinmektedir $(8,9)$.

İki yaş altı çocuklarda viral patojenler içinde \%40 ile ilk sırayı respiratuar sinsitiyal virüs (RSV) almaktadır. Daha az sıklıkla adenovirus, bocavirus, insan metapneumovirus, influenza A ve B, parainfluenza, coronavirus ve rinovirus görülmektedir (10). Epidemiyolojik çalışmalarda \%2-33 oranında 2 veya daha fazla virus etken olarak gösterilmektedir (11).

Toplum kökenli pnömoni tanısı ile izlenen olguların \%2-50'sinde bakteriyal patojenler izole edilmektedir $(9,12)$. Viral ve bakteriyal patojenlerin birlikteliği \%23 oranında gösterilmektedir (12).

Atipik pnömoni etkeni \%3-23 oranında izole edilmekte, süt çocuğunda C. Pneumonia ve daha büyük çocuklarda M. Pneumonia izole edilen patojendir $(8,12)$. Erişkinden farklı olarak Legionella çocuklarda nadiren izole edilmektedir (13).

Pnömoniye tek bir yaklaşım ya da tedavi protokolü yoktur ancak geliştirilen rehberler ile mortalite ve morbiditenin azaltılması amaçlanmaktadır (14). Çocuklarda toplum kökenli pnömoni çok farklı klinik seyir gösterebilir. Aynı mikroorganizma ile farklı klinik tablolar görülebilir.

Tablo 1: Çocuklarda yaşa göre pnömoni etkenleri

\begin{tabular}{|c|c|c|}
\hline Yaş & En sık etken & Nadir etken \\
\hline 2-24 ay & $\begin{array}{l}\text { Respiratory syncytial virus } \\
\text { Human metapneumovirus } \\
\text { Parainfluenza viruses } \\
\text { Influenza A ve B } \\
\text { Rhinovirus } \\
\text { Adenovirus } \\
\text { Enterovirus } \\
\text { Streptococ cus pneumoniae } \\
\text { Chlamydia trachomatis }\end{array}$ & $\begin{array}{l}\text { Mycoplasma pneumoniae } \\
\text { Haemophilus influenzae (type B ve tiplendirilemeyen) } \\
\text { Chlamydophila pneumoniae }\end{array}$ \\
\hline 2-5 yaş & $\begin{array}{l}\text { Respiratory syncytial virus } \\
\text { Human metapneumovirus } \\
\text { Parainfluenza viruses } \\
\text { Influenza A ve B } \\
\text { Rhinovirus } \\
\text { Adenovirus } \\
\text { Enterovirus } \\
\text { S. Pneumoniae } \\
\text { M. Pneumoniae } \\
\text { H. Influenzae (B ve } \\
\text { tiplendirilemeyen } \\
\text { C pneumoniae }\end{array}$ & $\begin{array}{l}\text { Staphylococcus aeresus (MRSA dahil) } \\
\text { Group A streptococcus }\end{array}$ \\
\hline$>5$ yaş & $\begin{array}{l}\text { M. Pneumoniae } \\
\text { C. Pneumoniae } \\
\text { S. Pneumoniae } \\
\text { Rhinovirus } \\
\text { Adenovirus } \\
\text { Influenza A ve B }\end{array}$ & $\begin{array}{l}\text { H. İfluenzae (B ve tiplendirilemeyen } \\
\text { S. aureus (MRSA dahil) } \\
\text { Group A streptococcus } \\
\text { Respiratory syncytial virus } \\
\text { Parainfluenza viruses } \\
\text { Human metapneumovirus } \\
\text { Enterovirus }\end{array}$ \\
\hline
\end{tabular}


Ülkemizde 2002 yılında Türk Toraks Derneği tarafından çocuklarda toplum kökenli pnömoni tanı ve tedavi rehberi, yine Türk Toraks Derneği tarafından 2009 yılında çocukluk çağı toplum kökenli pnömoni tanı ve tedavi uzlaşı raporu yayınlanmıştır $(15,16)$. En son 2011 tarihinde Amerikan Çocuk İnfeksiyon Derneği tarafından üç yaş ve üstü çocuklarda toplum kökenli pnömoniye yaklaşım rehberi yayınlanmıştır (17). Bu çalışmada en son yayınlanan rehber eşliğinde çocuklarda toplum kökenli pnömoniye yaklaşım irdelenecektir. Bu rehberde 3 ay altı, immunsuprese, evde ventilatör desteği görenler ve kistik fibroz gibi kronik akciğer hastalığı olan olgular kapsam dışında bırakılmışlardır. Toplam 92 öneriden oluşmaktadır.

\section{Ana başlıklar}

Tedavi kararı

Tanısal testler

İlaç tedavisi

Cerrahi ve ilaç-dışı tedavi

Taburculuk kriterleri

Korunma

\section{Tedavi Kararı}

\section{I- Toplum kökenli pnömoni de ne zaman hastaneye yatış önerilir?}

Çocuklar için pnömoni nedeniyle hastaneye yatış kriterleri için validiye skorlama sistemi yoktur. Mevcut skorlama sistemleri erişkin çalışmalarından modifiye edilmiştir (18).

1- Orta veya ağır pnömoni geçiren olgular yatarak tedavi edilmelidirler. Tablo 2 'de solunum sıkıntısı kriterleri verilmiştir.

2- 3-6 aydan küçük çocuklar bakteriyal pnömoni düşünülüyorsa yatarak tedavi edilmelidirler.

3- Yüksek virulansa sahip patojenlerin yol açtığı pnömoniler yatarak tedavi edilmelidir (MRSAmetisilin dirençli staphylococcus aureus gibi).

4- Evde bakımı ve takibi yeterli olmayan olgular yatarak tedavi edilmelidir.

Türk Toraks Derneği "çocuklarda toplum kökenli pnömoni tanı ve tedavi uzlaşı raporu" 2 ayın altındaki tüm çocukların, 2 ayın üstünde ağır ve çok ağır pnömonisi olan, altta yatan hastalığı olan, tekrarlayan pnömonilerin, ayaktan tedavi
Tablo 2: Pnömoni tanısı ile izlenen çocuklarda solunum sıkıntısı kriterleri

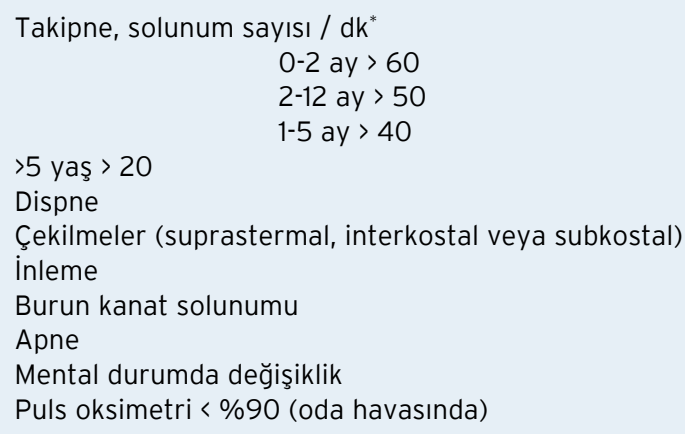

Dispne

Çekilmeler (suprastermal, interkostal veya subkostal)

İnleme

Burun kanat solunumu

Apne

Mental durumda değişiklik

Puls oksimetri < \%90 (oda havasında)

*Who kriterlerinden adapte edilmiştir

sırasında progresyon gösteren, akciğer grafisinde multilober tutulum, atelektazi, apse, plevral efüzyonu olan ve sosyal endikasyonu olan (evde bakımı yetersiz ya da tedaviye uyumu yeterli olmayan) çocukların hastanede tedavisini önermektedir (16). Toksik görünüm net tanımlanamasa da Tablo 2' de belirtilen bulgulara göre tüm dünyada hastaneye yatış kriteri olarak kabul edilmektedir (18).

\section{II- Toplum kökenli pnömoni de ne zaman yoğun bakıma yatış önerilir?}

Yoğun bakımda izleme kriterleri Tablo 3'de verilmiştir (19).

\section{Tablo 3: Yoğun bakımda izleme kriterleri}

\begin{tabular}{l} 
Majör Kriterleri \\
İnvaziv mekanik ventilasyon intiyacı \\
Sıvı tedavisine rağmen şok \\
Non-invasive pozitif basınçıı ventilasyon intiyacı \\
Yüksek +FiO2 intiyacı gösteren hipoksemi \\
Minör Kriterler \\
Solunum sayısının WHO kriterlerinden yüksek olması \\
Apne \\
Artmış solunum yükü (çekilme, inleme, burun kanat solunumu) \\
^PaO2/FiO2 < 250 \\
Multilobar infiltrasyon \\
*PEW skoru > 6 \\
Mental durumda değişiklik \\
Hipotansiyon \\
Plevral effüzyon \\
Komorbidite (HbSS, immünsupresyon, ummunye temizlik) \\
Açıklanamayan metabolik asidoz \\
\hline ?1 majör veya >2 minör kriteri karşılayan olgular yoğun bakımda izlenmelidirler. \\
+FiO2: fraksiyonu oksijen basıncı. \\
^PaO2/FiOz: Paniyel oksijen basıncının fonksiyonel oksijen basıncına oranı. \\
*PEV skoru (pediatrik erken uyarı skoru)
\end{tabular}


5- Entübasyon desteğine gerek duyan olgular

6- Non-invaziv ventilasyon desteği gösteren olguların sürekli monitorizasyonu için

7- Solunum yetmezliği geliştirmesi beklenen olgular

8- Taşikardi, kan basıncı düşük olan ve destek tedavisi gerektiren olgular

9- Oksijen satürasyonu $<\% 92\left(\mathrm{FiO}_{2} \geq 0.50\right.$ iken $)$

10- Pnömoniye bağlı hiperkarbi veya hipoksi nedeniyle mental durumu bozulmuş olgular

11- Pnömoni ağırlık skoru yüksek olan olgular klinik, laboratuar ve radyolojik bulgularına göre yoğun bakımda izlenmelidir.

Yapılan çalışmalarda invasiv pnömokok enfeksiyonlarında özellikle viral etkenlerle bir arada olduğu durumlarda, MRSA pnömonilerin de yoğun bakım ihtiyacı yüksek olup, yoğun bakım süreci uzun olmaktadır $(20,21)$.

\section{Tanısal Testler}

III. Poliklinik veya serviste yatan olgularda hangi laboratuar ve görüntüleme yöntemlerini istemeliyiz?

\section{Kan kültürü: Poliklinik hastası}

12- Aşıları tam, genel durumu düşkün görünmeyen olgulardan kan kültürü alınmasına gerek yoktur

13- Antibiyotik tedavisi sonrası klinik tablosu kötüye giden, beklenen düzelmeyi göstermeyen olgulardan kan kültürü gönderilmelidir.

Pnömoni tanısı ile ayaktan tedavi edilen olgularda kan kültürünün yalancı pozitif oranı yüksek olduğundan ve kan kültüründe üreme \%2'nin altında olduğundan kan kültürü önerilmemekte$\operatorname{dir}(22)$.

\section{Kan kültürü: Yatan hasta}

14- Bakteriyal pnömoni düşünülen, orta ve ağır kliniği olan olgulardan özellikle komplike pnömonisi olan olgulardan kan kültürü gönderilmelidir.

15- Taburcu olması için yeterli kriteri dolduran ancak kan kültüründe üreme saptanan ya da kan kültürü sonucu bekleyen olgular yakın takip edilebilecekse uygun antibiyotik tedavisi başlanıp taburcu olabilir.
16- Pnömokok bakterimisi olan ancak kliniği düzelen olgularda kan kültürü tekrarlamaya gerek yoktur.

17- Kan kültüründe $S$. aureus üremiş olan olgular klinikleri düzelse de kan kültürü temiz olana kadar tedavileri devam etmelidir.

Ayaktan tedavi edilen olguların aksine yatarak tedavi gören olgularda kan kültüründe üreme $\%$ 3-11.4 oranında bildirilmiştir $(22,23)$.

\section{Balgam kültürü:}

18- Hastanede yatarak tedavi olan ve balgam çıkarabilen tüm hastalardan balgam kültürü gönderilmelidir.

19- Yanlış pozitiflik oranı yüksek olduğu için pnömokok pnömonisi tanısı koymak için idrarda antijen tarama testi önerilmemektedir.

Balgam kültürü için uygun örnek almak güç ancak bakteriyal enfeksiyonun tanısında oldukça yararlı bir tanı yöntemidir.

\section{Viral Testler}

20- Poliklinikten takipli veya serviste yatan olgularda İnfluenza ve diğer virüslerin hızlı tanısını sağlayacak sensitivitesi ve spesifisitesi yüksek testler antibiyotik kullanımını kısıtlayacağı için önerilmektedir.

21- Influenza testi pozitif olan, bakteriyal pnömoni açısından klinik, laboratuar ve radyolojik bulguları olmayan olgulara poliklinik veya serviste yatsa da antibiyotik tedavisi başlanmamalıdır.

22- Influenza dışı respiratuarvirus tarama testleri bakteriyal pnömoni kliniği olmayan olgularda antibiyotik tedavisini kısıtlayacağı için önerilmektedir.

Randomize ve prospektif klinik çalışmalar, influenza testinin yapılmasının diğer yardımcı testlerin istenmesini ve antibiyotik kullanımını anlamIı oranda azalttığını ileri sürmektedir $(24,25)$.

\section{Atipik Patojenlerin Testi}

23- Mikoplazma pnömonisi düşünülen olgularda antibiyotik seçimine yardımcı olacağından tanısal testler önerilmektedir.

24- Klamidya pnömonisi için güvenilir testler olmadığı için tanısal test önerilmemektedir. 
Makrolid kullanımını kısıtlayacağı için mikoplazmaya yönelik testler önerilmektedir ancak günümüzdeki mevcut testlerden hiçbiri hastalığın herhangi döneminde yapıldığında yüksek spesifitesi ve sensitiviteye sahip değildir.

\section{Yardımcı Testler}

\section{Tam kan sayımı}

25- Poliklinikte pnömoni şüphesi olan olgularda tam kan sayımına gerek yoktur ancak ağır vakalarda yaklaşım açısından yararlı olabilir.

26- Ağır pnömonili olgularda tam kan sayımı yapılmalı, diğer laboratuar ve görüntüleme yöntemleri ile değerlendirilmelidir.

Pnömoni tanısı ile izlenen olguların çoğunda beyaz hücre sayısı yüksek olup bakteriyal ve viral ayrıma yardımcı olmamaktadır. Öte yandan beyaz küresi yüksek olan çocukların çoğunda pnömoni saptanmamaktadır (26).

\section{Akut Faz Reaktanları}

27- Sedimentasyon hızı, C-reaktif protein (CRP) veya serum prokalsitonin düzeyleri viral ya da bakterial patojeni ayırmada yeterli değillerdir.

28- Akut faz reaktanları aşıları tam çocuklarda poliklinikten pnömoni tanısı ile takip edilenlerde rutinde istenmemelidir. Ağır enfeksiyonlarda klinik yaklaşımda yararlı bilgiler verebilirler.

29- A ̆̆ır pnömoni nedeniyle hastaneye yatan veya pnömoniye bağlı komplikasyon görülen olgularda akut faz reaktanları tedaviye yanıtı değerlendirmede kullanılabilirler.

Akut faz reaktanları viral ya da bakteriyal patojeni ayırmada yeterli değillerdir ancak hastanede yatarak tedavi gören olgularda başlangıçta bakılan CRP veya prokalsitonin düzeyinde düşme klinik düzelme ile korrele olabileceğinden pnömoni rezolüsyonunun objektif bir bulgusu olabi$\operatorname{lir}(27)$.

\section{Puls Oksimetri}

30- Pnömoni şüphesi olan tüm olgularda puls oksimetri bakılmalıdır. Hipoksemi varlığı tedavinin nerede verileceğini ve ileri tanısal testlere ihtiya$\mathrm{cr}$ belirler

\section{Akciğer Grafisi}

\section{ilk Akciğer Grafisi: Poliklinik hastaları}

31- Poliklinikte takip edilebilecek kadar kliniği iyi olan olgularda pnömoni tanısını koymak için akciğer grafisine gerek yoktur.

32- Solunum sıkıntısı olan veya hipoksemisi olan olgularda PA ve lateral akciğer grafisi önerilmektedir. Antibiyotik tedavisine yanıt vermeyen olgularda parapnömonik efüzyon, nekrotizan pnömoni ve pnömotoraks gibi komplikasyonları değerlendirmek için akciğer grafisi önerilmektedir.

\section{ilk Akciğer Grafisi: Yatan hasta}

33- Pnömoni tanısı ile servise yatırılan tüm olgularda PA ve lateral akciğer grafisipnömoninin varlığı, yaygınlığı ve parankimin filtrasyonunun yapısını belirlemek, komplikasyonları saptamak ve tedaviyi düzenlemek için gereklidir.

\section{Kontrol Akciğer Grafisi}

34- Tedaviye yanıtı beklendiği gibi olan olgularda kontrol akciğer grafisine gerek yoktur.

35- Beklenen klinik düzelme olmadığında, antibiyotik tedavisinin 48-72 saati içinde kliniği bozulan olgularda kontrol akciğer grafisi önerilmektedir.

36- Parapnömonik effüzyon nedeniyle gögüs tüpü takılan veya VATS yapılan olguların kliniği stabilse kontrol akciğer grafisi önerilmemektedir.

37- Solunum sıkıntısı olan komplike pnömonili olgularda, tedavinin 48-72'inci saatinde ateş yüksekliği devam ediyorsa kontrol akciğer grafisi önerilir.

38- Aynı lobda tekrarlayan pnömonisi olan, anotomik patoloji, kitle veya yabancı cisim aspirasyonu düşünülen olgularda 4-6 hafta sonra kontrol akciğer grafisi önerilmektedir.

Literatür bilgisi rutin kontrol akciğer grafisinin klinik değerinin çok kısıtlı olduğu buna karşın çocuklara gereksiz radyasyona maruziyete sebep olduğu yönündedir (28).

\section{Ağır pnömonilerde ilave tanısal testler nelerdir?}

39- Endotrakeal tüp takılıp mekanik ventilatör desteği verilen olgularda viral ve bakteriyal patojenle- 
rin tespiti için trakeal aspirat kültürü önerilmektedir.

40- İmmunitesi yeterli ancak ilk tanısal testleri sonuç vermeyen ağır pnömonisi olan olgularda bronko-alveolar lavaj (BAL), açık akciğer biyopsi önerilebilir

Tablo 4'te poliklinik ve yatan hastalara yaklaşımda önerilenler özetlenmektedir.

\begin{tabular}{lll}
$\begin{array}{l}\text { Tablo 4: Çocuklarda } \\
\text { Yaklaşım }\end{array}$ & & \\
\hline Test & Yapmalı mıyım? & Öneri \\
\hline & Poliklinik hastası & \\
Puls oksimeteri & Evet & Bazı durumlarda \\
Akc grf & Hayır & Bazı durumlarda \\
Kontrol Akc grf & Hayır & Influenza sezonunda \\
Influenza testi & Evet & Makrolid kullanacaksan \\
Mikoplazma testi & Evet & \\
Balgam & Hayır & Evet düzelme yoksa \\
Kan kültürü & Hayır & \\
Hemogram & Hayır & \\
& Yatan Hasta & \\
Puls oksimeteri & Evet & \\
Akc grf & Evet & \\
Kontrol Akc grf & Hayır & \\
Influenza testi & Evet & \\
Mikoplazma testi & Evet & \\
Balgam & Evet & \\
Kan kültürü & Evet & \\
Hemogram & Hayır & \\
& &
\end{tabular}

\section{ilaç Tedavisi}

\section{Poliklinik ve serviste yatan hastalara hangi antibi- yotik tedavisi verilmelidir?}

Toplum kökenli pnömoninin ampirik tedavisi çocuğun yaşına ve olası patojene göre düzenlenmelidir.

\section{Poliklinik Hastaları}

41- Okul öncesi çocuklarda pnömoni nedeni büyük oranda viral patojenler olduğu için antibiyotik tedavisi önerilmemektedir.

42- Bakteriyal pnömoni düşünülen aşıları tam okul öncesi çocuklarda ilk seçilecek antibiyotik Amoksisilin olmalıdır. Amoksisilin en sık bakteriyal pnömoni etkeni olan streptococcus pneumoniae karşı yeterli etki göstermektedir.

43- Hafif ve orta pnömonisi olan aşıları tam daha önce sağlıklı okul çocuğu ve adolesanlarda seçilecek ilk antibiyotik Amoksisilin olmalıdır. Atipik patojenler ve diğer bakteriyal etkenler de düşünülmelidir.

44- Atipik patojen düşünülüyorsa okul çağı ve adolesanlarda seçilecek antibiyotik makrolid türevi olmalıdır. M. Pneumoniae için laboratuar testleri de önerilmektedir.

45- İnfluenza salgını varsa, orta ve ağır pnömoniler de olgunun kliniği bozuluyorsa influenza sonucunu beklemeden antiviral tedavi başlanabilir. Erken başlanan tedavi maksimum yarar sağlar ancak 48 saat sonra özellikle ağır vakalarda antiviral tedavi başlanabilir.

Türk Toraks Derneği "çocuklarda toplum kökenli pnömoni tanı ve tedavi rehberi" ayaktan tedavide 5 yaşın altında Amoksisilin, 5 yaş üzerinde yine Amoksisilin, atipik patojen düşünülüyorsa Makrolid grubu antibiyotikleri önermektedir (16).

\section{Yatan hasta}

46- Aşısı tam, okul çağı çocuklarına serviste yatıyorsa ve penisilin direnci yüksek değilse ilk seçilecek antibiyotik ampisilin veya penisilin G olmalıdır.

47- Aşısı tam olmayan, penisilin direnci yüksek olan bölgelerde yaşayanlara, hayati tehlikesi, ampiyemi olan süt çocuğu veya çocuklarda ilk seçilecek antibiyotik seftriakson olmalıdır. Seftriakson direnci yüksek olan bölgelerde vankomisin 3 . kuşak sefalosporinlere göre daha etkin bulunmuştur.

48- Atipik pnömoni düşünülen olgularda makrolid tedavisi beta laktam ile kombine olarak verilmesi önerilmektedir.

49- S. Aureus düşünülen olgularda beta laktama ilaveten vankomisin ya da klindamisin önerilmektedir.

Poliklinik ve yatan hastalara başlanacak ampirik antibiyotik tedavisi Tablo 5 ve 6'da özetlenmiştir. Bakteriyal ve viral ko-infeksiyon özellikle influenza virüsü ile $S$. Pneumonia, S. Aureus (hem metisilin hassas ve dirençli dahil) ve grup $A$ streptococcus arasında görülmektedir. Bazı olgulara hem anti-bakteriyal hem de anti-viral ampirik tedavi verilmelidir. 
Tablo 5: Ayaktan izlenen olguların ampirik pnömoni tedavisi

\begin{tabular}{|c|c|c|c|}
\hline Poliklinik & Bakterial pnömoni & Atipik pnömoni & Viral pnömoni \\
\hline$<5$ yaş & $\begin{array}{l}\text { Amoksisilin } \\
\text { (90mg/kg/gün } 2 \\
\text { dozda) } \\
\text { Alterne } \\
\text { Amoksisilin-klavunat } \\
\text { (90mg/kg/gün } 2 \text { doz) }\end{array}$ & $\begin{array}{l}\text { Azitromisin } \\
(10 \mathrm{mg} / \mathrm{kg} / \mathrm{g} 1 . g u ̈ n, 5 \\
\mathrm{mg} / \mathrm{kg} / \mathrm{g} 2-5 \text { gün } \\
\text { Alterne } \\
\text { Klaritromisin } \\
(15 \mathrm{mg} / \mathrm{kg} / \mathrm{g} 2 \text { dozda } \\
7-10 \text { gün })\end{array}$ & Oseltamivir \\
\hline ?5 yaş & $\begin{array}{l}\text { Amoksisilin } \\
\text { (90mg/kg/gün } \\
\text { dozda, max } 4 \mathrm{gr} / \mathrm{g}) \\
\text { Makrolid eklenebilir } \\
\text { Alterne } \\
\text { Amoksisilin-klavunat } \\
\text { (90mg/kg/gün } 2 \text { doz, } \\
\text { max 4g/gün) }\end{array}$ & $\begin{array}{l}\text { Azitromisin } \\
(10 \mathrm{mg} / \mathrm{kg} / \mathrm{g} 1 . \text { gün, } 5 \\
\mathrm{mg} / \mathrm{kg} / \mathrm{g} 2-5 \text { gün, max } \\
500 \mathrm{mg} 1 . \text { gün, } 250 \mathrm{mg} \\
2-5 \mathrm{gün}) \\
\text { Alterne } \\
\text { Klaritromisin } \\
\text { (15 mg/kg/g } 2 \text { dozda } 7- \\
10 \text { gün, } \mathrm{max} 1 \text { gr/gün) }\end{array}$ & $\begin{array}{l}\text { Oseltamivir veya } \\
\text { zanamivir (? } 7 \text { yaş) } \\
\text { Alterne } \\
\text { Peravimir, oseltamivir } \\
\text { veya zanamivir (IV) }\end{array}$ \\
\hline
\end{tabular}

Tablo 6: Pnömoni tanısı ile yatarak tedavisi gören hastaların ampirik antibiyotik tedavisi

\begin{tabular}{|c|c|c|c|}
\hline Yatan hasta & Bakterial pnömoni & Atipik pnömoni & Viral pnömoni \\
\hline $\begin{array}{l}\text { Hib ve pnömokok aşısı } \\
\text { tam, pnömokok direnci } \\
\text { düşük }\end{array}$ & $\begin{array}{l}\text { Ampisilin veya Pen G } \\
\text { Alterne } \\
\text { Seftriakson veya } \\
\text { sefotaksim } \\
\text { MRSA varsa klindamisin } \\
\text { veya vankomisin ekle }\end{array}$ & $\begin{array}{l}\text { Azitromisin ve B laktam } \\
\text { Alterne } \\
\text { Klaritromisin veya } \\
\text { Doksosiklin } 7 \text { yaş, } \\
\text { levofloksasiklin } \\
\text { matürasyon tamsa }\end{array}$ & $\begin{array}{l}\text { Oseltamivir veya zanamivir } \\
\text { (? } 7 \text { Yaş) } \\
\text { Alterne } \\
\text { Peramivir, oseltamivir } \\
\text { veya zanamivir (IV) }\end{array}$ \\
\hline $\begin{array}{l}\text { Hib ve pnömokok aşısı } \\
\text { eksik, pnömokok direnci } \\
\text { yüksek }\end{array}$ & $\begin{array}{l}\text { Seftriakson veya } \\
\text { sefotaksim } \\
\text { MRSA varsa klindamisin } \\
\text { veya vankomisin ekle }\end{array}$ & $\begin{array}{l}\text { Azitromisin ve B laktam } \\
\text { Alterne } \\
\text { Klaritromisin veya } \\
\text { Doksosiklin } 7 \text { yaş, } \\
\text { levofloksasiklin } \\
\text { matürasyon } \\
\text { tamsa }\end{array}$ & $\begin{array}{l}\text { Oseltamivir veya zanamivir } \\
\text { (? } 7 \text { Yaş) } \\
\text { Alterne } \\
\text { Peramivir, oseltamivir } \\
\text { veya zanamivir (IV) }\end{array}$ \\
\hline
\end{tabular}

Türk Toraks Derneği "çocuklarda toplum kökenli pnömoni tanı ve tedavi rehberi" 5 yaş altı yatarak tedavi gören çocuklarda Penisilin G, Ampisillin-Sulbaktam, Amoksisilin-Klavunat, veya Sefuroksimi önermekte, çok ağır vakalarda Sefotaksim veya Seftriakson önermektedir (16). Beş yaş üstü çocuklarda ise Penisilin veya Ampisilin, atopik patojen düşünülüyorsa Makrolid eklenmesini, çok ağır vakalarda ise yine Sefotaksim veya Seftriakson Makrolid kombinasyonu ile önermektedir.

\section{Antibiyotik direncini önlemek için ne yapılabilir?}

50- Gerekli olmadıkça antibiyotik tedavisi önerilmemelidir.
51- Olası patojene yönelik antibiyotik seçilmelidir 52- Minimal etkin dozda antibiyotik kullanılmalıdır

53- Tedavi süresi mümkün olduğunca kısa tutulmaIıdır.

En düşük dozda etkili ve dirence neden olmayacak antibiyotik çalışması henüz yapılmamıştır.

\section{Antibiyotik tedavi süresi ne olmalıdır?}

54- Önerilen tedavi süresi 10 gündür ancak hafif olgularda daha kısa süre tedavi verilebilir

55- MRSA gibi patojenlerin tedavisi daha uzun sürmelidir

Parapnömonik effüzyon, ampiyem, veya akciğer absesi gibi komplike infeksiyonlarda tedavi 10 günden fazla olmalıdır. Bazı araştırıcılar effüz- 
yon ya da ampiyemin drene olmasından sonra ateşsiz 7-10 gün geçene kadar, bazıları da 4-6 hafta tedavinin devamını önermektedir. Akciğer absesi varlığında klinik, laboratuar ve görüntüleme yöntemleri ile antimikrobiyal tedavinin süresi kişiye özel olmalıdır.

\section{Tedaviye beklenen yanıt nasıl değerlendirilme- lidir?}

56- Tedavi etkinliği 48-72 saat içinde klinik ve laboratuar bulgularında düzelme ile değerlendirilir. Tedaviye beklenen yanıt vermeyen olgularda ileri tetkiklere gidilmelidir.

\section{Cerrahi ve illaç-dışı Tedavi}

\section{Parapnömonik effüzyon nasıl tanı konur?}

57- Hikaye ve fizik muayene bulguları ile parapnömonik effüzyon düşünülen olgulara akciğer grafisi ile yeterli bilgi alınamadığı durumlarda akciğer ultrasonu veya bilgisayarlı tomografi (Toraks BT) önerilir

Radyasyona maruziyeti azalttığından akciğer ultrasonu Toraks $\mathrm{BT}^{\prime}$ ye tercih edilmelidir.

\section{Parapnömonikeffüzyon ne zaman tedavi edilmeli?}

58- Plevral effüzyona yaklaşımda effüzyon miktarı tedaviyi etkiler.

59- Plevral effüzyona yaklaşımda solunum sıkıntısı tedaviyi etkiler.

\section{XI.Plevral sıvıda hangi testler yapılmalıdır?}

60- Gram boyama, bakteriyal kültür önerilir.

61- Patojenin identifikasyonun da polimeraz zincir tepkimesi (PCR) önerilir.

62- Plevral sıvının incelenmesi $\mathrm{pH}$, glukoz, protein, LDH tedaviyi nadiren değiştireceği için önerilmemektedir.

63- Plevral sıvıda beyaz küre (BK) ve hücre sayımı, mikobakteriyal etiyolojileri ve malignansiyi ekarte ettirebileceğinden önerilmektedir

\section{Parapnömonik effüzyon tedavisi}

64- Küçük komplike olmayan plevral effüzyonlar drene edilmemelidir, antibiyotik tedavisi yeterlidir.
65- Solunum sıkıntısına yol açan orta büyüklükte (>10 mm), büyük effüzyonlar veya pürülan effüzyonlar drene edilmelidir.

66- Gögüus tüpü, fibronolitik ajan tedavisi ile ve video yardımlı torakoskopik cerrahi (VATS) plevral effüzyon için önerilen yöntemlerdir. Seçim cerrahın tecrübesine göre yapılmalıdır. Büyük effüzyonlar özellikle loküle değilse gögüs tüpü takılarak, fibronolitik ajan uygulanmaksızın drene edilmelidir.

Parapnömonik effüzyona yaklaşım Tablo 7'te verilmiştir.

XIII. Göğüs tüpü olan olgularda ne zaman VATS ya da açık dekortikasyon tercih edilmelidir?

67- Gögüs tüpü ve fibronolitik tedaviye rağmen (2-3 gün) devam eden solunum sıkıntısı varsa VATS önerilmektedir. Açık dekortikasyon alternatif bir yöntem olmakla beraber daha yüksek morbidite oranına sahiptir.

\section{Göğüs tüpü ne zaman çekilmelidir?}

68- İntratorasik hava kaçağı yoksa, plevral sıvı drenajı son 12 saatte $<1 \mathrm{ml} / \mathrm{kg} / 24$ saat ise tüp çekilebilir.

\section{Parapnömonik effüzyon/ ampiyemin antibiyotik tedavisi}

69- Kan kültürü veya plevral sıvı kültüründe üreme varsa antibiyograma göre antibiyotik seçilmelidir.

70- Kültürlerde üreme yoksa hastanede yatan olgulara önerilen tedavi rejimi verilmelidir.

71- Tedavinin süresi her hastada drenaj durumuna ve klinik cevaba göre değişik olabilir. Çoğunlukla 2-4 hafta antibiyotik tedavisi yeterli olmaktadir.

\section{Tedaviye dirençli olgulara yaklaşım}

72- Antibiyotik tedavisine 48-72 saat içinde yanıt vermeyen olgularda önerilenler a- Klinik ve laboratuar değerlendirme sonucu bakımın daha üst derecede verilmesi b- Pnömonik veya parapnömonik komplikasyonlar açısından görüntüleme yöntemleri kullanılmalıdır

c- Patojen ajanın direnci ya da sekonder pato- 
jenlerin varlığı göz önüne alınmalıdır.

73- Mekanik ventilatörde olan çocuklarda BAL ile alınan sıvının gram boyama ve kültürü önerilmektedir

74- Çok ağır vakalarda perkütan akciğer aspirasyonu önerilmektedir

75- Çok ağır özellikle entübe olgularda tanı amaçlı açık akciğer biyopsisi önerilmektedir.

Hastanede yatarak tedavi alan pnömonili olguların \%5-15'inin tedaviye yanıt vermeyeceği ileri sürülmektedir (29).

XVII. Tedaviye cevap vermeyen akciğer absesi ya da nekrotizan pnömoni varlığında ne yapılmalı?

76- Pulmoner abse veya nektrotizan pnömonili olgular intravenöz antibiyotik ile tedavi edilmelidir. Periferal yerleşimli bronşiyal dallara yakın olmayan abseler drene edilmelidir.

\section{Taburculuk Kriterleri}

77- Aktivitesi, iştahı düzelen olgular en az 12-24 saat ateşsiz ise taburcu olabilirler.

78- Puls oksimetri oda havasında 12-24 saat boyunca $>\% 90$ ise taburcu olabilirler.

79- Mental durumları stabilse taburcu olabilirler

80- Takipnesi veya taşikardisi devam eden olgular taburcu edilmemelidirler.

81- Evde verilecek intravenöz veya oral antibiyotik tedavisini tolere edebiliyorsa, gerektiği durumlarda eve oksijen temin edilebiliyorsa taburcu edilebilirler.

82- Çocuğun bakımında sorumlu kişiler tedaviye uyumlu ise taburcu edilebilirler.

83- Göğüs tüpü çekildikten 12-24 saat sonra kliniklerinde bozulma yoksa plevral sıvı oluşumu önemsiz ise, pnömotoraks saptanmamışsa taburcu edilebilirler.

84- Taburcu edilmeden önce tüm olgular evde tedavi ve takip açısından değerlendirilmelidirler.

En güvenilir taburculuk kriterlerine yönelik bir çalışma olmamasına rağmen yukarıda sayılan kriterler göz önüne alınmaktadır.

\section{Ne zaman oral ya da paranteral antibiyotik ter- cih edilmelidir?}

85- Taburcu olurken parenteral tedavi ihtiyacı olan olgular bakım verecek kişiler bilgilendirilerek yakın takip yapılabilecekse taburcu edilmelidirler.

86- Taburcu olurken parenteral tedavi eve hemşire gelebiliyorsa ya da sağlık kurumunda yapılmak şartıyla önerilmelidir.

87- Mümkün olan en kısa sürede oral tedaviye geçilmelidir.

Ayaktan parenteral tedavi komplikasyonları göz önüne alındı̆̆ında oral tedaviyi tolere edemeyen, veya dirençli bakteri nedeniyle oral antibiyotik tedavi verilemeyen olgulara uygulanmalı$\operatorname{dir}(30)$.

\section{Toplum Kökenli Pnömonide Önlem}

\section{Toplum kökenli pnömoni önlenebilir mi?}

88- Tüm çocuklara S. Pnömoni, H. İnfluenza tip b ve boğmaca aşısı yapılmalıdır.

89- Altı ay ve üstü tüm çocuklara ve adolesanlara yıllık gip aşısı yapılmalıdır.

90- Altı aydan küçük çocukların bakımını üstlenen kişilere grip aşısı ve boğmaca aşıları yapılmalıdır

91- Influenza aşılaması ile influenza infeksiyonundan sonra görülen pnömokok infeksiyonlarında azalma görülmüştür.

92- Yüksek riskli çocuklar ağır pnömoni ve hastaneye yatış riskini azaltmak için RSV profilaksisine alınmalıdır.

Tüm dünyada en sık çocukluk çağı toplum kökenli pnömoninin bakteriyal etkeni S. Pnömoni ve $\mathrm{H}$. İnfluenza tip b olup, 5 yaş altında ölümlerin yarısından sorumludur (31). Konjuge pnömokok aşısının ve H. İnfluenza tip b konjuge aşısının rutin aşılama programına girmesi ile morbidite ve mortalite önemli oranda azalmıştır $(32,33)$.

Çocuklarda influenza virus infeksiyonları bakteriyal pnömoni ile birlikte görülebilmektedir. İnaktive trivalan influenza aşısı \%86 ( \%95 güvenilirlik aralığı \%29-97) oranında koruma sağlamaktadır (34). Bakteriyal pnömoni özellikle metisilin dirençli S. Aureus pnömonisi, komplike pnömoniler influenza pandemileri ile ilişkilendirildiğinden CDC Aşılama Komitesi ve Amerikan pediatri akademisi (AAP) 6 ay ve üstündeki tüm çocuklara influenza aşısı yapılmasını önermek- 
tedir (35).

RSV süt çocuğunda en sık toplum kökenli pnömoniye neden olan viral patojendir (36). Palivizumab (synagis) uygulaması ile RSV'ye bağlı hastaneye yatış oranı azalmıştır (37). Palivizumab kullanımı ile ilgili rehber AAP tarafından yayınlanmıştır (38).

Koruyucu tedavide aşılama önemli ancak daha önemlisi ebeveynlerin, toplumun eğitimidir. Anne sütünün önemi, sağlıklı beslenme, hijyen, sigara içiminin engellenmesi, hastalığın tanınması ve izlemi konusunda toplumun eğitimi korunmada temel strateji olmalıdır.
Toplum kökenli pnömoni çocuklarda özellikle 5 yaş altında önemli bir morbidite ve mortalite nedenidir. En ileri tanı yöntemlerinin kullanıldığı çalışmalarda bile etkenlerin ancak \%50'si tanımlanabilmektedir. Günümüzde çocuklarda toplum kökenli pnömoninin tanı ve tedavisi için erişkin kadar olmasa da pek çok rehber yayınlanmaktadır. Bu rehberler ile pnömoniye yaklaşımda uygun standartların oluşturulması, akılcı antibiyotik kullanımı ve antibiyotik direncinin önlenmesi, sonuç olarak pnömoniye bağlı morbidite ve mortalitenin azaltılması hedeflenmektedir.

\section{KAYNAKLAR}

1. Rudan I, Boschi-Pinto C, Biloglav Z, Mulholland K, Campbell H. Epidemiology and etiology of childhood pneumonia. Bul World Health Organ 2008; 86: 408-16.

2. Wardlaw T, Salama P, Johansson EW, Mason E. Pneumonia: the leading killer of children. Lancet 2006; 368: 1048-50.

3. Ünüvar N, Mollahaliloğlu S, Yardım N (editör). Türkiye Hastalık Yükü Çalışması 2004. T.C. Sağıı Bakanlığı, Refık Saydam Hıfzıssıhha Merkezı Başkanlığı, Hıfzıssıhha Mektebi Müdürlüğü. 1. Baskı. Ankara: Aydoğdu Ofset Matbaacılık San. ve Tic.Ltd.Şti; 2006; p.1-56.

4. Henrickson KJ. Viral pneumonia in children. Sem Pediatr Infect Dis J 1998; 9: 217-33.

5. Klein JO. Bacterial pneumonias. In: Feigin $R D$, Cherry JD, Demmler GJ, Kaplan SL (eds). Textbook of Pediatric Infectious Diseases. $4^{\text {th }}$ ed. Philadelphia: W.B. Saunders Company; 2004.p. 273-84.

6. Jadavji $T$, Law B, Lebel MH, Kennedy WA, Gold R, Wang EE. A practical guide for the diagnosis and treatment of pediatric pneumonia. CMAJ 1997; 156: 703-11.

7. Kumar S, Wang L, Fan J, Kraft A, Bose ME, Tiwari $S$, et al. Detection of 11 common viral and bacterial pathogens causing community-acquired pneumonia or sepsis in asymptomatic patients by using a multiplex reverse transcription-PCR assay with manual (enzyme hybridization) or automated (electronic microarray) detection. J Clin Microbiol 2008; 46: 3063-72.

8. Heiskanen-Kosma T, Korppi M, Jokinen C, Kurki S, Heiskanen $L$, Juvonen $H$, et al. Etiology of childhood pneumonia: serologic results of a prospective, population-based study. Pediatr Infect Dis J 1998; 17: 986-91.

9. Hamano-Hasegawa K, Morozumi M, Nakayama E, Chiba N, Murayama SY, Takayanagi N, et al. Comprehensive detection of causative pathogens using real-time PCR to diagnose pediatric community-acquired pneumonia. I Infect Chemother 2008; 14: 424-32.

10. Drummond P, Clark J, Wheeler J, Galloway A, Freeman R, Cant A. Community acquired pneumonia: a prospective UK study. Arch Dis Child 2000; 83: 408-12.

11. Bonzel L, Tenenbaum $T$, Schroten $H$, Schildgen $O$, SchweitzerKrantz $S$, Adams $O$. Frequent detection of viral coinfection in children hospitalized with respiratory tract infection using a realtime polymerase chain reaction. Pediatr Infect Dis J 2008; 27: 589-94.
12. Michelow IC, Olsen K, Lozano J, Rollins NK, Duffy LB, Ziegler $T$, et al. Epidemiology and clinical characteristics of communityacquired pneumonia in hospitalized children. Pediatrics 2004; 113: $701-7$.

13. Ng V, Tang P, Jamieson F, Guvard C, Low DE, Fisman DN. Laboratory-based evaluation of legionellosis epidemiology in Ontario, Canada, 1978 to 2006. BMC Infect Dis 2009; 9: 68.

14. Dean NC, Bateman KA, Donnelly SM, Silver MP, Snow GL, Hale $D$. Improved clinical outcomes with utilization of a communityacquired pneumonia guideline. Chest 2006; 130: 794-9.

15. Ece T, Arman D, Akalın H, Alataş F, Biberoğlu K, Çakar N ve ark. Toraks Derneği Erişkin ve Çocuklarda Hastane Kökenli Pnomöniler Tanı ve Tedavi Rehberi. Toraks Dergisi 2002; 3(Ek sayı 3): S1-13.

16. Kocabaş E, Doğru-Ersöz D, Karakoç F, Tanır G, Cengiz AB, Gür $D$ ve ark. Türk Toraks Derneği Çocukluklarda Toplumda Gelişen Pnömoni Tanı ve Tedavi Uzlaşı Raporu. Toraks Dergisi 2009; 10(Ek sayı 3): S1-24.

17. Bradley JS, Byington CL, Shah SS, Alverson B, Carter ER, Harrison $C$, et al. Pediatric Infectious Diseases Society and the Infectious Diseases Society of America.The management of communityacquired pneumonia in infants and children older than 3 months of age: clinical practice guidelines by the Pediatric Infectious Diseases Society and the Infectious Diseases Society of America. Clin Infect Dis 2011; 53: e25-76.

18. Jadavji $T$, Law B, Lebel MH, Kennedy WA, Gold R, Wong EE. A practical guide for he diagnosis and treatment of pediatric pneumonia. CMAJ 1997; 156: 703-11.

19. Mandell LA, Wunderink RG, Anzueto A, Bartlett JG, Campbell $G D$, Dean NC, et al. Infectious Diseases Society of Americal American Thoracic Society consensus guidelines on the management of community-acquired pneumonia in adults. Clin Infect Dis. 2007; 44(Suppl 2): S27-72.

20. Castaldo ET, Yang EY. Severe sepsis attributable to communityassociated methicillin-resistant Staphylococcus aureus: an emerging fatal problem. Am Surg 2007; 73: 684-7.

21. Techasaensiri B, Techasaensiri C, Mejias A, McCracken $G H$ $J r$, Ramilo O. Viral coinfections in children with invasive pneumococcal disease. Pediatr Infect Dis J 2009; 29: 519-23.

22. Hickey RW, Bowman MJ, Smith GA. Utility of blood cultures in pediatric patients found to have pneumonia in the emergency department. Ann Emerg Med 1996; 27: 721-25. 
23. Byington $C L$, Spencer $L Y$, Johnson TA, Pavia AT, Allen D, Mason $E O$, et al. An epidemiological investigation of a sustained high rate of pediatric parapneumonic empyema: risk factors and microbiological associations. Clin Infect Dis 2002; 34: 434-40.

24. Bonner AB, Monroe KW, Talley LI, Klasner AE, Kimberlin DW. Impact of the rapid diagnosis of influenza on physician decisionmaking and patient management in the pediatric emergency department: resuls of a randomized, prospective, controlled trial. Pediatrics 2003; 112: 363-7.

25. Abanses JC, Dowd MD, Simon SD, Sharma V. Impact of rapid influenza testing at triage on management of febrile infanst and young children. Pediatr Emerg Care 2006; 25: 1153-7.

26. Korppi M, Heiskanen-Kosma T, Leinonen M. White blood cells, C-reactive protein and erythrocyte sedimentation rate in pneumococcal pneumonia in children. Eur Respir J 1997; 10: 1125-9.

27. Prat C, Dominguez J, Rodrigo C, Gimenez M, Azuara M, Jimenez $O$, et al. Procalcitonin, C-reactive protein and leukocyte count in children with lower respiratory tract infection. Pediatr Infect Dis J 2003; 22: 963-8.

28. Virkki R, Juven T, Mertsola J, Ruuskanen O. Radiographic followup of pneumonia in children. Pediatr Pulmonol 2005; 40: 223-7.

29. Menendez $R$, Torres A. Treatment failure in community-acquired pneumonia. Chest 2007; 132: 1348-55.

30. Ruebner $R$, Keren $R$, Coffin S, Chu J, Horn D, Zaoutis TE. Complications of central venous catheters used for treatment of acute hematogenous osteomyelitis. Pediatrics 2206; 117: 1210-5.

31. World pneumonia day: November 2, 2009. Available at: http://www.cdc.gov/mmwr/preview/mmwrhtml/mm5842a6.htm. Accessed 10 February 2015.
32. Whitney CG, Farley MM, Hadler J, Harrison LH, Bennett NM, Lynfield $R$, et al. Decline in invasive pneumococcal disease after the introduction of protein-polysaccharide conjugate vaccine. $N$ Engl J Med 2003; 348: 1737-46.

33. Adams WG, Deaver KA, Cochi SL, Plikaytis BD, Zell ER, Broome $C V$, et al. Decline of childhood Haemophilus influenza type $b$ (Hib) disease in the Hib vaccine era. JAMA 1993; 269: 221-6.

34. Joshi AY, lyer VN, St Sauver $J L$, Jacobson JM, Boyce TG. Effectiveness of inactivated influenza vaccine in children less than 5 years of age over multiple influenza seasons: a casecontrol study. Vaccine 2009; 27: 4457-61.

35. Centers for Disease Control and Prevention. ACIP provisional recommendations for the use of influenza vaccines. 2010. Available at: http://www.cdc.gov/mmwr/pdf/rr/rr59e0729.pdf. Accessed 20 February 2015.

36. Hall CB, Weinberg GA, Iwane MK, Blumkin AK, Edwards KM, Staat MA, et al. The burden of respiratory syncytial virus infection in young children. N Engl J Med 2009; 360: 588-98.

37. Meissner HC, Bocchini JA Jr, Brady MT, Hall CB, Kimberlin DW, Pickering $L K$. The role of immunoprophylaxis in the reduction of disease attributable to respiratory syncytial virus. Pediatrics 2009; 124: 1676-9.

38. Bocchini JA Jr, Bernstein HH, Bradley JS, Brady MT, Byington $C L$, Fisher MC, et al. Committee on Infectious Diseases. From the American Academy of Pediatrics; policy statements- modified recommendations for use of palivizumab for prevention of respiratory syncytial virus infections. Pediatrics 2009; 124: 1694701. 